\title{
Effect of the use of different types of fishmeal on the physicochemical properties of a fishfeed for Oreochromis niloticus (Nile tilapia)
}

\section{Efecto del uso de diferentes tipos de harina de pescado en las propiedades fisicoquímicas de un alimento para Oreochromis niloticus (tilapia del Nilo)}

\author{
SOTO-RODRÍGUEZ, Diana Laura†, GÓMEZ-ALDAPA, Carlos Alberto, CABRERA-CANALES, \\ Zaira Esmeralda and CADENA-RAMÍREZ, Arturo*
}

\begin{abstract}
Universidad Politécnica de Pachuca, Pachuca-Cd highway. Sahagún, Km 20, Ex-Hacienda de Santa Bárbara, municipality of Zempoala, Hidalgo, Mexico. C. P. 43830.
\end{abstract}

ID $1^{\text {st }}$ Author: Diana Laura, Soto-Rodríguez / CVU CONACYT ID: 673637

ID $1^{\text {st }}$ Coauthor: Carlos Alberto, Gómez-Aldapa / ORC ID: 0000-0002-4723-3093, CVU CONACYT ID: 20051

ID $2^{\text {nd }}$ Coauthor: Zaira Esmeralda, Cabrera-Canales / ORC ID: 0000-0002-0062-1654, CVU CONACYT ID: 555694

ID $3^{\text {rd }}$ Coauthor: Arturo, Cadena-Ramírez / ORC ID: 0000-0003-2813-8186, CVU CONACYT ID: 42647

DOI: $10.35429 /$ EJE.2020.12.7.8.14

Received January 11, 2020; Accepted June 30, 2020

\begin{abstract}
The objective of this research was to study the effect of two types of fishmeal on the physicochemical properties of extruded food for Oreochromis niloticus (Nile tilapia). Using Pearson's squares, a diet was formulated (moringa, fish meal and corn flours, gelatin and vitamin and mineral premixes) with a protein content of 30 to $32 \%$. The fish meal (sardine or salmon) was added in a $23.7 \%$ with respect to total composition of diet. The treatments were moistened with 13 and $17 \%$ water and processed in a single screw laboratory extruder. Extruded foods and a commercial (control), were analyzed according to their moisture, apparent density (DA), expansion index (IE), water absorption index (IAA), water solubility index (ISA), hardness and bulk density. The foods formulated with salmon flour at both moistures and with sardine flour at $17 \%$ humidity floated at $100 \%$. The IE and DA values of food with salmon meal were like those of the commercial feed. Concluding that, the type of fishmeal used in the formulation of extruded foods influences the physicochemical properties of the product.
\end{abstract}

Extruded food, Fishmeal, Oreochromis niloticus

\begin{abstract}
Resumen
El objetivo de esta investigación fue estudiar el efecto de dos harinas de pescado sobre las propiedades fisicoquímicas de alimentos extrudidos para Oreochromis niloticus (tilapia del Nilo). Mediante cuadrados de Pearson, se formuló una dieta a base de harinas de moringa, pescado y maíz, grenetina, premezclas vitamínica y mineral, con un contenido de proteína del 30-32\%. La harina de pescado (sardina o salmón) se adicionó en un $23.7 \%$ con respecto a la composición total de la dieta. Los tratamientos se humectaron con agua al 13 y $17 \%$ y se procesaron en un extrusor de laboratorio de tornillo simple. Los alimentos extrudidos y un alimento comercial (control), fueron analizados de acuerdo con su humedad, índice de expansión (IE), densidad aparente (DA), índice de absorción de agua (IAA), índice de solubilidad en agua (ISA), dureza y flotabilidad. Los alimentos con harina de salmón a ambas humedades y con harina de sardina al $17 \%$ de humedad flotaron al $100 \%$. Los valores de IE y de DA de los alimentos con harina de salmón fueron similares a los del alimento comercial. Concluyendo que el tipo de harina de pescado utilizado en la formulación de los alimentos extrudidos influye en las propiedades fisicoquímicas del producto.
\end{abstract}

Alimentos extrudidos, Harina de pescado, Oreochromis niloticus

Citation: SOTO-RODRÍGUEZ, Diana Laura, GÓMEZ-ALDAPA, Carlos Alberto, CABRERA-CANALES, Zaira Esmeralda and CADENA-RAMÍREZ, Arturo. Effect of the use of different types of fishmeal on the physicochemical properties of a fishfeed for Oreochromis niloticus (Nile tilapia). ECORFAN Journal-Ecuador. 2020. 7-12:8-14.

\footnotetext{
* Correspondence to Autor (E-mail: arturocadena@upp.edu.mx)

$\dagger$ Researcher contributing as first author.
} 


\section{Introduction}

Feeding in the aquaculture sector represents 50 to $80 \%$ of the production cost (Hasan, 2017), therefore, the study of aquaculture feeds is important, as proteins are essential for the stages of growth, maintenance, and reproduction of any living organism. In Nile tilapia (Oreochromis niloticus), protein deficiency can induce growth retardation, reduced appetite and, on occasions, deformation of the spine (Llanes et al., 2006). The optimal protein content in the ration for tilapia depends on the size or age and ranges from 30 to 50\% (Rokey et al., 2010).

In addition to the protein content, the Nile tilapia requires floating food, since this species feeds on the surface of pond waters, for this, extrusion technology has been used, which consists of mixing various ingredients, transporting them and thermoforming them in a system of low humidity, high temperatures and high pressures, for a short time, using shear forces originated by a screw (Gil, 2010). During extrusion, proteins are one of the main components affected, because not all of them behave in a similar way (Navarro-Cortez, 2010).

The native proteins are denatured, due to the combined effect of temperature, pressure and shear forces, factors applied inside the extruder barrel, and that promote the increase of the digestibility of the proteins present in the extruded products, mainly due to their denaturation and by the inactivation of antinutritional factors, which decrease its digestibility (Onwulata et al., 2003 \& Singh et al., 2007). The temperature used during the extrusion process, together with the absence of considerable amounts of starch, can reduce the solubility of proteins, consequently losing their functional properties (Pérez-Navarrete et al., 2006). In extruded products, with a high starch content, the protein undergoes encapsulation, however, the digestive enzymes of the intestinal tract of the fish dissolve the starch matrix, releasing the protein (Pérez-Robles et al., 2008).

In the production of extruded food, another main factor that directly affects the quality of the food is the initial water content. An increase in the processing humidity allows to obtain higher expansion rates, which influence a greater buoyancy of the product and a greater stability in water (Silva and Anderson, 1995).
The initial humidity is also related to the degree of gelatinization of the starch present in the food, however, in processes with low moisture content, gelatinization of the starch can be induced by mechanical cuts to the granules generated by high shear forces. inside the extruder (Vesanthan et al., 2001). The degree of gelatinization of starch is associated with the water absorption index (IAA) and the water solubility index (ISA), physicochemical properties that indicate the amount of water absorbed by the starch granules, while a high value of the ISA indicates the content of soluble solids generated by the gelatinization of starch and by the depolymerization and debranching of the polymeric starch chains during the extrusion process (Kannadhason et al., 2009; Singh et al., 2016 \& Lu et al., 2019). For this study, it has been decided to work with initial humidity of 13 and $17 \%$ because in preliminary tests and under these conditions it has been possible to obtain dry food, with which it is intended to reduce the cost of making the product.

Currently there are no specifications for the formulation of aquaculture feeds, it is known that the main protein source is fish meal, however, the source of this meal is at the discretion of the manufacturer, therefore, in this investigation the behavior of the source of the fish meal (sardine or salmon) at different percentages of initial moisture (13 and 17\%) in the mixture (moringa, corn and fish meal, gelatin, vitamin and mineral premix), on the physicochemical characteristics of the food extruded, comparing the responses obtained with those of a commercially available food used as a control, in order to determine its application as food for Nile tilapia.

The development of the work is presented in 4 sections: itroduction, methodology to be developed, results and discussion and conclusions. In the methodology to be developed, the techniques and conditions used to obtain the food are described, as well as the techniques for the physicochemical characterization of the products and commercial food. The results and discussions section presents the results obtained from the physicochemical characterization of extruded food comparing it with a commercial food. The last section presents the conclusions of this research. 


\section{Methodology to be developed}

\section{Obtaining extruded feed for Nile tilapia}

The diet formulated using Pearson's squares (50.4\% moringa flour, $23.7 \%$ fish flour, $13 \%$ corn flour, $6 \%$ gelatin, $3 \%$ vitamin premix and $3 \%$ mineral premix) was extruded according to the methodology reported by Pérez-Nurseries (2017) with some modifications. At 13 and 17\% humidity, two batches (the first with sardine flour and the second with salmon flour) were processed in a single screw laboratory extruder, Brabender $25 \mathrm{~L} / \mathrm{D}$ brand. Where the heating zones were kept at 80, 100, 125 and $125{ }^{\circ} \mathrm{C}$, from the feed zone to the exit zone, respectively, the screw used had a compression ratio of $2: 1$, the feed and screw speeds were 60 and $160 \mathrm{rpm}$ respectively and the exit die used was $4 \mathrm{~mm}$.

\section{Physicochemical characterization of extruded feed}

\section{Determination of humidity}

AOAC (1990) method 925.09 was used. In trays at constant weight, $3 \mathrm{~g}$ of sample were added, and they were kept in the oven at $130{ }^{\circ} \mathrm{C}$ for 1 hour, finally the tray with the dry sample was weighed. The moisture percentage was calculated by weight difference according to equation (1).

$\%$ Humidity $=\left(\frac{\mathrm{P}_{\mathrm{i}}-\mathrm{P}_{\mathrm{f}}}{\mathrm{m}}\right) \cdot 100$

Where:

$\mathrm{Pi}=$ Weight of the tray with sample at the beginning $(\mathrm{g})$. Pf $=$ Weight of the tray with sample at the end $(\mathrm{g}) \cdot \mathrm{m}=$ Weight of the sample (g).

\section{Expansion index (IE) and apparent density (DA)}

The EI was calculated according to the methodology reported by Gujska and Khan (1990), dividing the diameter of the extruded feed (pellet) by the diameter of the orifice of the extruder exit die. AD was calculated according to the methodology reported by Wang et al. (1993). With a vernier (Songqi tolos, Stainless Hardened, China) the diameter of 20 samples of $2.5 \mathrm{~cm}$ in length was measured.
The diameter was reported as the average of 3 measurements throughout the extrudate and each of the samples was weighed. The DA was determined as the weight of the sample over the volume of the extrudate, which was calculated with equation (2).

$V=\pi \cdot r^{2} \cdot h$

Where:

$\mathrm{V}=$ Volume, $\mathrm{r}=$ radius and $\mathrm{h}=$ height.

\section{Water absorption index (IAA) and water solubility index (ISA)}

The ISA and IAA were determined according to the methodology of Anderson et al. (1970), with some modifications. $1 \mathrm{~g}$ of sample (pellets) was weighed on a dry basis, $10 \mathrm{~mL}$ of distilled water were added in a $50 \mathrm{~mL}$ Falcon tube, the tube with the sample and the water was stirred for $1 \mathrm{~min}$ in a vortex (IKA-WERKE, lab dancer, Germany) and centrifuged in a centrifuge (Hermle, 2300, Germany) at $6000 \mathrm{rpm}$ for $30 \mathrm{~min}$. After time, the supernatant was decanted into aluminum trays, previously placed at constant weight, the trays were dried in an oven (Sel lab, USA) for 24 $\mathrm{h}$ at $110^{\circ} \mathrm{C}$. The tube with the solid sample was weighed again. The IAA represented the amount of water retained per gram of sample, while the ISA, was expressed as the percentage of dissolved solids in the supernatant.

\section{Hardness}

Hardness analysis was carried out on a texturometer (Texturolab, TA.XT-Plus, UK). 60 extruded foods from each treatment (pellets), with a length of $0.5 \mathrm{~cm}$, were analyzed. Hardness was calculated as the force required to cut the product by a compression test. The probe used was a $25 \mathrm{~mm}$ cylindrical probe at a distance of 2 $\mathrm{mm}$, a force of $0.049 \mathrm{~N}$, a return distance of 10 $\mathrm{mm}$, a return velocity of $10 \mathrm{~mm} / \mathrm{s}$ and a contact force of $100 \mathrm{~g}$. The result was reported as the average of the 60 measurements in units of newtons. 


\section{Buoyancy}

To determine the buoyancy of extruded food in pellet form, the method of Vargas (2003) was used, with some modifications. The number of pellets that floated after 30 min was recorded in a $500 \mathrm{~mL}$ cylinder. The result was reported in percentage after analyzing a total of 10 samples.

\section{Statistic analysis}

A one-way ANOVA was used and the comparison of means $(\mathrm{p} \leq 0.05)$ was carried out with the Tukey-Kramer test using the NCSS 12 Data Analysis Software Manuals program.

\section{Results and Discussion}

\section{Determination of humidity}

The results of the moisture content in the treatments with salmon and sardine meals are shown in Graphic 1, where it is observed that after the extrusion process, the humidity of the extruded foods decreased between 5 and $7 \%$ with respect to its initial humidity that is, the feeding humidity (13 and 17\% respectively), not observing statistically significant differences $(p \leq 0.05)$ between the treatments. Food extruded at $17 \%$ initial moisture presented moisture percentages like that of commercial food.

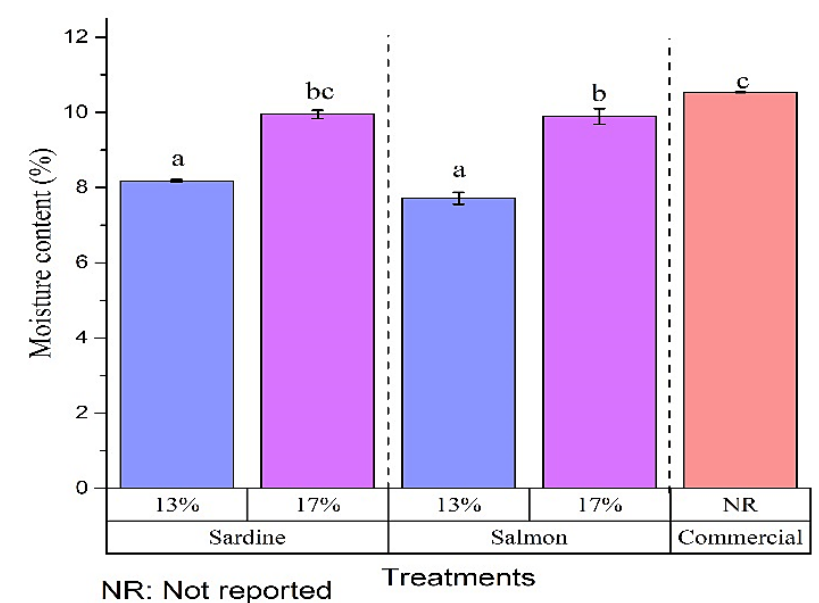

Graphic 1 Moisture content

Source: Our elaboration

\section{Expansion index (IE) and apparent density (DA)}

The EI results obtained (Graphic 2) were similar to those reported by Kannadhason et al. (2009), where extruded foods with higher DA values presented lower EI.
The EI decreased significantly when using salmon meal in the formulation, probably due to the type and content of protein present in the meal, since, according to Martin et al. (2019), the different types of proteins can undergo structural changes during the extrusion process, and that interfere with the degree of expansion of the pellet.

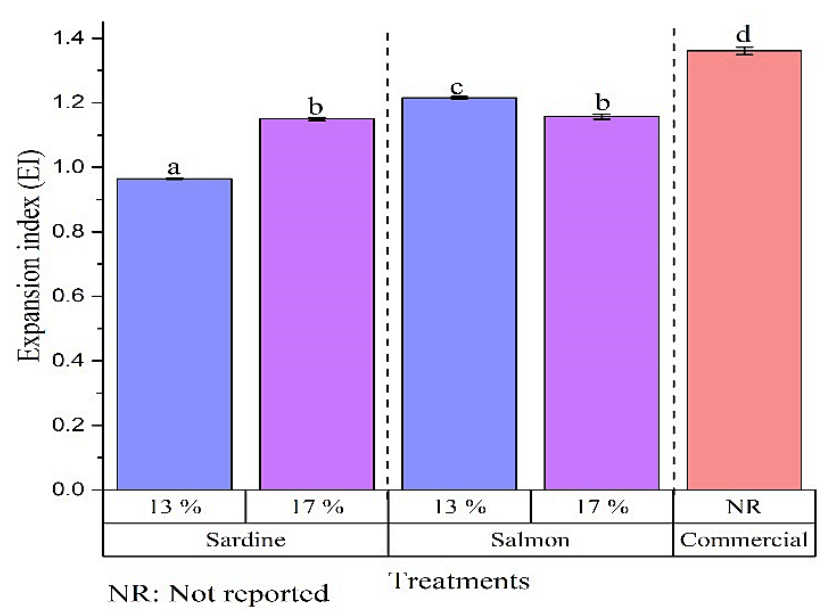

Graphic 2 Expansion index (IE)

Source: Our elaboration

The DA results (Graphic 3) agree with those reported by Xuelian et al. (2018) who report lower DA in extruded foods processed at higher humidities. Lower DA was observed in extruded foods made with salmon flour, attributed to the water solubility of its components, including proteins (Samuelsen et al., 2013), however, in order to assert this information it is necessary to perform a profile of proteins from each of the flours present in the formulation of the treatments used to obtain extruded foods. Finally, the results indicated that foods similar to commercial food were those extruded at $17 \%$ humidity, where despite obtaining higher DAs, buoyancy was not affected (Graphic 7).

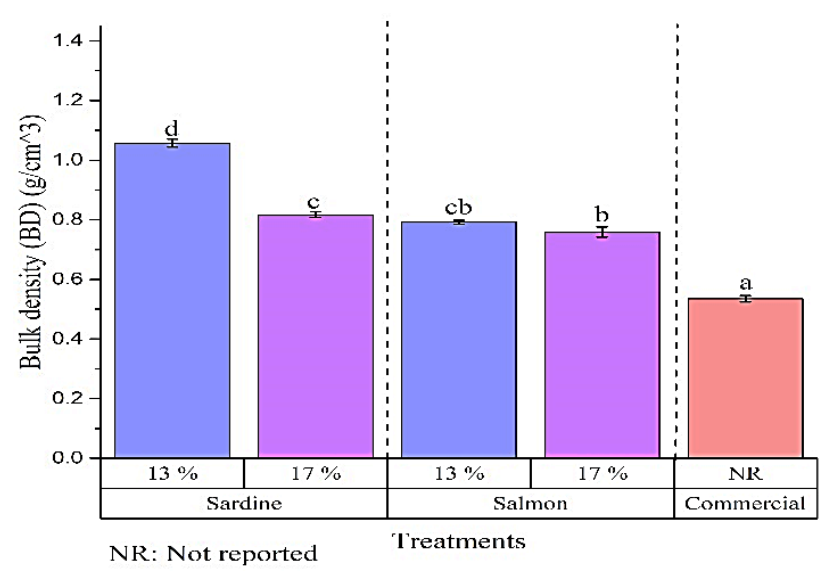

Graphic 3 Apparent density (DA)

Source: Our elaboration

SOTO-RODRÍGUEZ, Diana Laura, GÓMEZ-ALDAPA, Carlos Alberto, CABRERA-CANALES, Zaira Esmeralda and CADENARAMÍREZ, Arturo. Effect of the use of different types of fishmeal on the physicochemical properties of a fishfeed for Oreochromis niloticus (Nile tilapia). ECORFAN Journal-Ecuador. 2020 


\section{Water absorption index (IAA) and water solubility index (ISA)}

The IAA was slightly higher in extruded foods formulated with salmon flour at $17 \%$ humidity (Graphic 4), attributed to the interaction between the hydroxyl groups $(\mathrm{OH})$ of the starch from the corn flour and the $\mathrm{OH}$ groups of water present in the food, since according to Lu et al., (2019) IAA is related to the proportion of fully gelatinized starch granules that tend to absorb water. In these results, the diet formulated with salmon flour at $17 \%$ humidity did not show statistically significant differences $(\mathrm{p} \leq 0.05)$ with respect to commercial food.

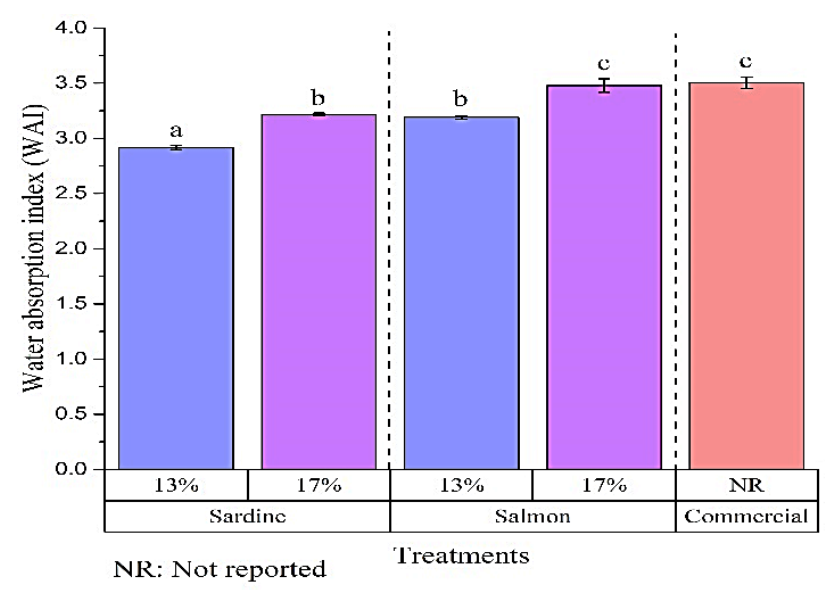

Graphic 4 Water absorption index (IAA) Source: Our elaboration

The ISA results (Graphic 5), did not present statistically significant differences $(p \leq 0.05)$ with respect to the feeding humidity; however, the treatments formulated with salmon meal presented higher ISA, probably due to the content of water-soluble proteins present in each of the fish meals, such as albumin.

The increase in ISA also indicated a greater degradation of the polymeric chains of starch during extrusion, being beneficial for their assimilation by losing their crystalline structure (Singh et al., 2016).

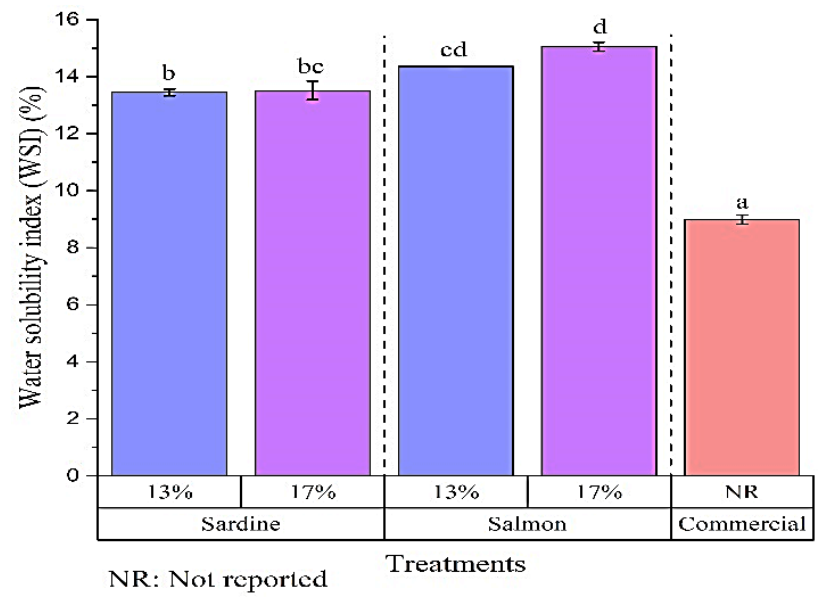

Graphic 5 Water solubility index (ISA) Source: Our elaboration

\section{Hardness}

The hardness of the extruded feeds decreased as the feed moisture content increased (Graphic 6). The lowest result was found in foods extruded with sardine flour at a feeding humidity of $17 \%$, a diet that did not show statistically significant differences ( $p<0.05$ ) with respect to commercial food, while the results of the rest of the diets they were found above it. The extruded diets at $17 \%$ moisture showed values closer to commercial food, however, an increase in the hardness of the pellet could not be detrimental as it contributes to the strength of the pellet for storage (Xuelian et al., 2018).

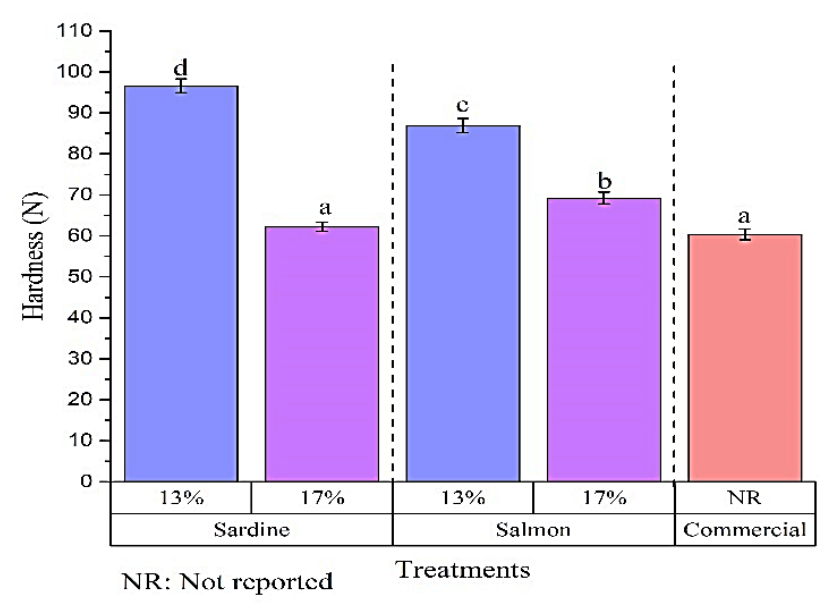

Graphic 6 Hardness

Source: Our elaboration

\section{Buoyancy}

The diets formulated with $17 \%$ feed moisture showed $100 \%$ buoyancy (Graphic 7), while in the extruded feed with $13 \%$ feed moisture, only those formulated with salmon meal showed $100 \%$ buoyancy while those formulated with sardine flour showed $0 \%$ buoyancy. 


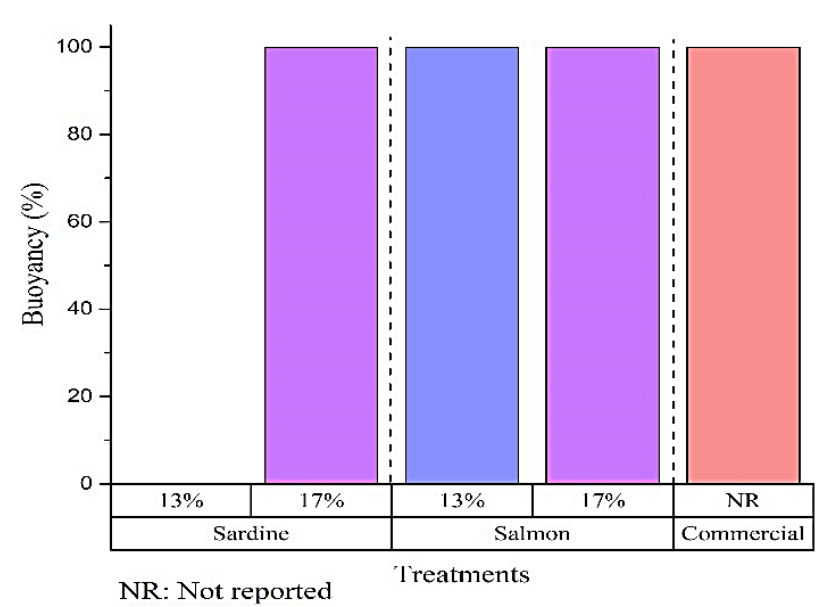

Figure 7 Buoyancy

Source: Our elaboration

\section{Conclusions}

The type of fish meal (salmon and sardine) used in the formulation of extruded foods influenced their physicochemical characteristics, being sardine meal the one that had the greatest influence on the characteristics of extruded foods, similar to those of the food. However, the diet with salmon meal at an initial feeding moisture of $17 \%$, substantially improved the physicochemical characteristics of the feed by increasing the expansion of the pellet, decreasing its apparent density and, consequently, contributed to increasing its buoyancy. The formulation and extrusion conditions allowed to obtain slightly harder food compared to commercial food, promoting a decrease in its fracture during storage and feeding of the fish, in addition to its nutritional properties are not affected since the solubility of the same in water is higher than that of commercial food, however, to assert this information, it is necessary to perform in vivo digestibility tests of the extruded food developed.

\section{References}

Anderson, R. A., Conway, H. F., and Peplinski, A. J. (1970). Gelatinization of Corn Grits by Roll Cooking, Extrusion Cooking and Steaming. Starch-stärke, 22(4), 130-135.

AOAC. (1990). Association of Official Analytical Chemists - Official methods of analysis. Volumen 1. The association of official analytical chemists. Arlingron, Virginia.

Gil, A. (2010). Tratado de nutrición. Panamericana. Madrid, España.
Gujska, E., and Khan, K. (1990). Effect of Temperature on Properties of Extrudates from High Starch Fractions of Navy, Pinto and Garbanzo Beans. Journal of Food Science, 55(2), 466-469.

Hasan, M. R. (2017). Feeding Global Aquaculture Growth. FAO Aquaculture Newsletter. 56, 1-3.

Kannadhason, S., Muthukumarappan, K. and Rosentrater, K. A. (2009). Effects of ingredients and extrusión parameters on aquafeeds containing DDGS and tapioca starch. Journal of aquaculture feed science and nutrition, 1(1), 6 21.

Llanes, J, Toledo, J., Fernandez, I., and Lazo, J. M. (2006). Nutrición y Alimentación de Tilapias. Revista de la Asociación Cubana de Producción Animal, 4, 51-54.

Lu, X., Brennan, M. A., Narciso, J., Guan, W., Zhang, J., Yuan, L. Serventi, L., and Brennan, C. S. (2019). Correlations between the phenolic and fibre composition of mushrooms and the glycaemic and textural characteristics of mushroom enriched extruded products. Food Science and Tecnology, 118.

Martin, A., Osen, R., Greiling, A., Karbstein, H. P., and Emín, A. (2019). Press cake and peel on the extruder response and physical pellet quality in extruded fish feed. Aquaculture, 512.

Navarro-Cortez, R.O. (2010). Caracterización fisicoquímica y estructural de botanas de tercera generación elaboradas a partir de harina de maíz (Zea mays L.) azul utilizando la tecnología de extrusión. Tesis Maestría en Ciencia y Tecnología de Alimentos. Universidad Autónoma de Sinaloa.

Onwulata, C.I., Konstance, R.P., Cooke, P.H., and Farrell, H.M. (2003). Functionality of extrusion-texturized whey proteins. Journal of Dairy Science, 86, 3775-3782.

Pérez-Navarrete, C., Cruz, R.H., Chel, L. y Betancur, AD. (2006). Caracterización física de extrudidos preparados con mezclas de harina de maíz QPM (Zea mays L.) y frijol lima (Phaseolus lunatus L.). Revista mexicana de ingeniería química, 5, 145-155. 
Pérez-Robles, Y., Morillo-Cabello, M. y Cardenas-Cuevas, C. 2008. La extrusión en la industria alimentaria. Alimentación, equipos y tecnología, 27(238), 40-43.

Pérez-Viveros, K. J. (2017). Formulación y desarrollo de un alimento extruido mediante la sustitución parcial de harina de pescado con harinas vegetales para Oreochromis niloticus (tilapia de nilo). Tesis de maestría. Universidad Politécnica de Pachuca. Zempoala, Hidalgo, México.

Rokey, G. J., Plattner, B., and Souza., E. M. (2010). Feed extrusion process description. Revista Brasileira de Zootecnia, 39, 510 - 518.

Samuelsen, T. A., Mjos, S. A., and Oterhals, A. (2013). Impact of variability in fishmeal physicochemical properties on the extrusion process, starch gelatinization and pellet durability and hardness. Animal Feed Science and Tecnology, 179(4), 77-84.

Singh, S., Gamlath, S., and Wakeling, L. (2007). Nutritional aspects of food extrusion: A review. International Journal of Food Science and Technology, 42(8), 916-929.

Singh, S. K., and Muthukumarappan, K. (2016). Effect of feed moisture, extrusion temperature and screw speed on properties of soy white flakes based aquafeed: a response surface análisis. Journal of the Science of Food and Agriculture, 96(6), 2220-2229.

Vargas, R., (2003). Evaluación preliminar del método utilizado en la determinación de la flotabilidad de alimentos piscícolas. Agronomia mesoamericana. 14(2), 193-199.

Wang, W. M., Klopfenstein, C. F., and Ponte, J. G. J. (1993). Effects of twin screw extrusion on the physical properties of dietary fiber and other components of whole wheat and wheat bran and on the baking quality of the wheat bran. Cereal Chemistry, 70(6), 707-711.

Xuelian, M., Bon-Yeob, G., Tie, J., Jin.Hyung, Y., Mi-Hwan, K., and Gi-Hyung R. (2018). Physicochemical Properties of Extruded Aquatic Pellets at Various Conditions. Food Engineering Progress, 22(3), 214-219. 